\title{
DESAIN DAN PEMBUATAN PROTOTIPE PULSE ELECTROMAGNETIC THERAPY (PEMFT) UNTUK STUDI BIOELEKTROMAGNETIK
}

\author{
Umiatin $^{1, \text { a), }}$ Tesa Apriyanti ${ }^{1}$, Sastra Kusuma Wijaya ${ }^{2}$ \\ 1) Program Studi Fisika Universitas Negeri Jakarta \\ ${ }^{2)}$ Departemen Fisika Universitas Indonesia \\ Email: a) ummiatin@yahoo.com
}

\begin{abstract}
Abstrak
Pulse Electromagnetic Therapy (PEMFt) atau lebih dikenal dengan PEMF merupakan salah satu modalitas yang disetujui oleh Food and Drug Administration (FDA) untuk membantu proses penyembuhan fraktur tulang non union (gagal sambung). Saat ini alat PEMF yang dijual dengan harga yang tidak murah, memiliki parameter fisis yang bervariasi sehingga dalam penggunaannya menghasilkan efektivitas beragam dan terkadang menimbulkan kontraindikasi. Dalam penelitian ini telah dilakukan desain, pembuatan dan uji coba prototipe alat PEMF menggunakan Arduino dan Labview. Tujuan dari penelitian ini adalah mendapatkan alat PEMF yang dapat digunakan dalam penelitian bioloektromagnetik. Penelitian dilakukan dalam tiga tahap yaitu tahap desain dan perancangan perangkat keras, desain dan perancangan perangkat lunak dan tahap ketiga adalah ujicoba alat PEMF untuk penelitian fraktur tulang menggunakan hewan coba tikus. Pada tahap pertama dibuat kumparan Helmholtz dengan diameter $40 \mathrm{~cm}$, jumlah lilitan 500, menggunakan kawat tembaga $0.7 \mathrm{~mm}$. Karakterisasi medan magnet yang dihasilkan dengan menggunakan Gaussmeter IDR 324 pada sumbu x, pada tegangan $18 \mathrm{~V}$ dan arus sebesar $0.28 \mathrm{~A}$, menghasilkan medan magnet homogen sebesar $0.4 \mathrm{mT}$. Pada tahap kedua dilakukan pembuatan kode program alat PEMF menggunakan Labview dan mikro kontroler Arduino Uno. Parameter fisis PEMF yang dikendalikan adalah waveform, frekuensi, duty cycle, burst time dan exposure time. Pembuatan antar muka dan pengolahan data dilakukan menggunakan program LabVIEW. Pada tahap ketiga telah dilakukan ujicoba prototipe alat PEMF yang dibuat untuk studi pada hewan coba yaitu tikus Spraque Dawley selama 28 hari.
\end{abstract}

Kata-kata kunci: Kumparan Helmholtz, PEMF, Bioelektromagnetik, Arduino Uno, LabVIEW.

\begin{abstract}
Pulse Electromagnetic Therapy (PEMFt) or better known as PEMF is one of the modalities approved by the Food and Drug Administration (FDA) to assist the healing process of non union bone fractures (failed connect). Currently PEMF equipment sold at a price that is not cheap, has a varying physical parameters so that in its use produce various effectiveness and sometimes contraindicated. In this research have been done design, manufacture and test prototype of PEMF tool using Arduino and Labview. The purpose of this research is to obtain PEMF tool which can be used in bioloectromagnetic research. The research was conducted in three stages, namely design and hardware design, design and software design, and the third step is PEMF testing for bone fracture research using mouse rats. In the first stage is made Helmholtz coil with a diameter of $40 \mathrm{~cm}$, the number of windings 500 , using $0.7 \mathrm{~mm}$ copper wire. The magnetic field characterization generated using Gaussmeter IDR 324 on the $\mathrm{x}$ axis, at a voltage of $18 \mathrm{~V}$ and a current of $0.28 \mathrm{~A}$, produces a homogeneous magnetic field of $0.4 \mathrm{mT}$. In the second stage, the programming of PEMF tools was made using Labview and Arduino Uno micro controller. The controlled PEMF physical parameters are waveform, frequency, duty cycle, burst time and exposure time. Interface creation and data processing is done using LabVIEW program. In the third
\end{abstract}


phase, a prototype PEMF test was made for a study of experimental animals of Spraque Dawley mice for 28 days.

Keywords: Helmholtz coil, PEMF, Bioelectromagnetic, Arduino Uno, LabVIEW.

\section{PENDAHULUAN}

Alat terapi medik berbasis elektromagnetik meliputi berbagai alat yang menggunakan listrik untuk menghasilkan medan listrik dan medan magnet, diantaranya adalah TENS (transutaneous electrical nerve stimulation), NMES (neuromuscular electrical stimulation), HVPG (high voltage pulsed galvanic) dan PEMF (pulse electromagnetic field). TENS, NMES dan HVPG menghasilkan medan listrik pada jaringan secara langsung karena adanya arus listrik yang dialirkan melalui kedua elektroda yang diletakkan pada jaringan target sehingga bersifat semi invasif. Pulse Electromagnetic Fields (PEMF) merupakan teknik non invasif yang bersifat induktif yaitu menghasilkan medan listrik pada jaringan karena adanya perubahan medan magnet. Munculnya medan listrik pada jaringan akan menyebabkan efek fisiologis pada sel yang disebabkan karena pergerakan ion antara lain $\mathrm{Ca}^{2+}, \mathrm{K}^{+}$, $\mathrm{Na}^{+}, \mathrm{Cl}^{-}$, yang merupakan proses penting dalam metabolisme sel [1].

Salah satu pemakaian PEMF yang telah disetujui oleh FDA adalah untuk membantu penyembuhan patah tulang non union. Seiring meningkatnya mobilitas penduduk saat ini, diestimasi hampir sekitar $10 \%$ fraktur tulang menunjukkan penyembuhan tidak sempurna sehingga menyebabkan non union dan delayed union. Tantangan utama bagi klinisi saat ini adalah mencari metode penyembuhan fraktur non union dan mencegah terjadinya delayed union secara efektif dan tidak berbiaya mahal [2].

PEMF telah cukup lama diteliti baik dalam skala in vitro (penelitian sel), pre klinis (penelitian hewan coba) maupun klinis, antara lain dilakukan oleh Ongaro dkk yang memberikan stimulus fisika berupa pajanan PEMF $(1.5 \mathrm{mT}, 75 \mathrm{~Hz})$ selama masa periode diferensiasi sel tulang yaitu 28 hari, diperoleh hasil terjadi peningkatankadar Alkaline phosphatase (ALP) dan Osteokalsin (OCL) yang merupakan penanda terjadinya pembentukan tulang (osteogenesis) [2].

Shi dkk melakukan penelitian klinis terhadap pasien dengan fraktur tulang panjang delayed union, 31 pasien menerima intervensi EMF dan 27 pasien sebagai kontrol. Diakhir pengobatan, berdasarkan penilaian radiologi diperoleh grup EMF menunjukkan laju penyembuhan sebesar $77.4 \%$ sedangkan pada kontrol sebesar $48.1 \%$ dengan waktu rata - rata total dari pertama penyembuhan sebelum diagnosa delayed union, grup EMF selama 9.6 bulan dan grup kontrol 9.5 bulan [3].

Meskipun beberapa studi menunjukkan efek positif penggunaan PEMF namun sampai saat ini bagaimana mekanisme sel diregulasi oleh stimulus PEMF tersebut masih belum dapat dijelaskan dengan baik. Beberapa penelitian lain menunjukan bahwa penggunaan PEMF tidak menimbulkan implikasi yang bermakna untuk membantu penyembuhan fraktur tulang. Hal ini akhirnya menimbulkan skeptisme penggunaan stimulus biofisika dalam bidang medis.

Salah satu penyebab bervariasinya efek PEMF dalam penelitian dikarenakan beragamnya parameter fisika yang dipakai para peneliti, meliputi jenis signal, intensitas medan magnetik, pulsed width, exposure time, frekuensi, beragamnya subyek penelitian serta peneliti yang memiliki beragam latar belakang keilmuan. Oleh karena itu, diperlukan penelitian komprehensif dan multidisiplin untuk mengevaluasi dan mengoptimasi parameter penting PEMF sehingga dapat menjelaskan mekanisme transduksi signal PEMF pada sel dan dapat menghasilkan respon seluler yang diharapkan. Untuk mencapai tujuan tersebut, perlu dikembangkan alat PEMF yang dapat mengirimkan dan memfokuskan stimulus ke target, jenis signal (pulse), intensitas, frekuensi serta exposure time yang adjustable dan user friendly yang dapat digunakan untuk penelitian invitro, preklinis maupun klinis mengenai penggunaan PEMF dalam bidang orthopaedi $[4,5,6]$. 


\section{METODE PENELITIAN}

\section{Pembuatan Hardware}

Alat PEMF yang dibuat terdiri dari : kumparan Helmholtz untuk menghasilkan medan magnet dan sensor pendeteksi intensitas medan magnet. Kumparan Helmholtz dibuat dengan diameter $45 \mathrm{~cm}$, menggunakan kawat tembaga $0.7 \mathrm{~mm}$ dengan jumlah lilitan 1000 lilitan. Dalam proses pengukuran dibutuhkan variasi arus dari 0-1 A untuk menghasilkan medan magnet dalam kisaran mT, oleh karena itu kumparannya terdiri dari 1000 lilitan yang masing-masing kumparan mempunyai 500 lilitan kawat tembaga dengan diameter $45 \mathrm{~cm}$ dan diameter kawat yang digunakan $0.7 \mathrm{~mm}$.

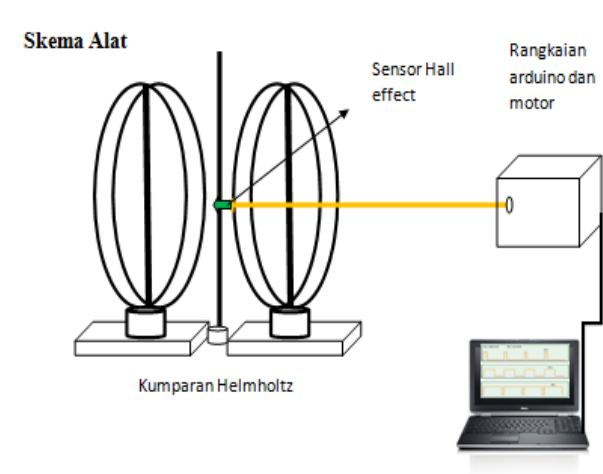

Gambar 1 a. Skema Alat PEMF

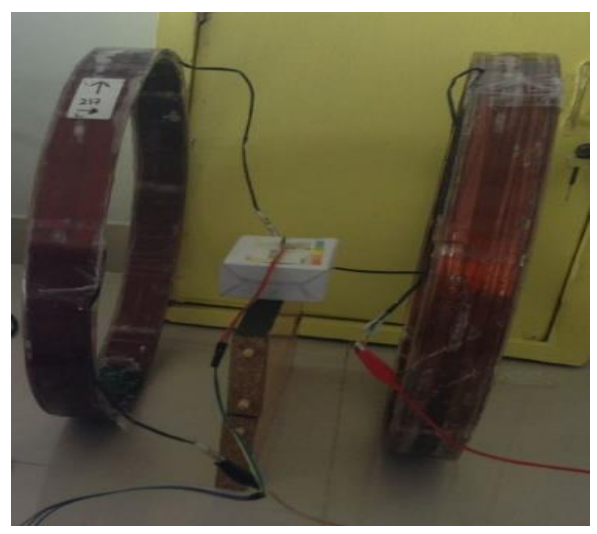

Gambar 1 b. Kumparan Helmholtz dan sensor medan magnet

Pendeteksian medan magnet ini menggunakan sensor Efek Hall. Sensor ini digerakkan secara manual menggunakan batang ulir gerakan kiri dan kanan (koordinat X), dengan jarak $10 \mathrm{~cm}$ dimulai dari pusat kumparan. Pada pergerakan sensor ke kanan dan kiri (koordinat X), digunakan batang ulir yang panjangnya kurang dari diameter kumparan medan magnet yakni sekitar $15 \mathrm{~cm}$. Batang ulir digunakan sebagai penentuan posisi sensor Efek Hall setiap perpindahan $1 \mathrm{~cm}$.

\section{Pembuatan Software}

Software LabVIEW berfungsi untuk mengontrol setting pengiriman data dan penerimaan data dari arduino yang kemudian ditampilkan pada komputer. Bahasa pemrograman pada software ini menggunakan icon-icon yang memiliki fungsi sebagai pengganti teks dalam membuat aplikasi. Berbeda dengan pemrograman berbasis teks dimana instruksi-instruksi menentukan eksekusi program, LabVIEW merupakan pemrograman aliran data dimana aliran data menentukan eksekusi dari program.

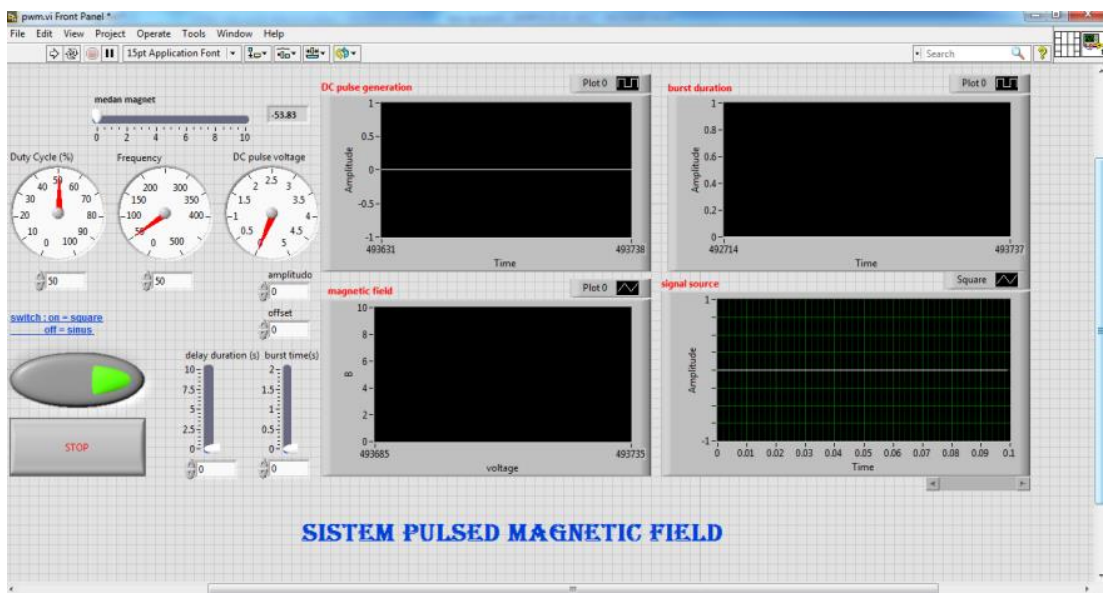

Gambar 2 Tampilan front panel LabVIEW 
Terdapat fungsi front panel dari tampilan LabVIEW yaitu fungsi kontrol dan fungsi indikator. Pada fungsi kontrol terdapat menu START dan STOP. Pada menu START akan mengawali atau memulai untuk menjalankan program, program akan memberitahu apa yang sedang berjalan termasuk pendeksian sensor yang otomatis menyimpan data, saat tombol switch on maka akan tampil jenis sinyal source yang keluar adalah square sedangkan saat switch off maka sinyal source yang muncul adalah sinusoidal.

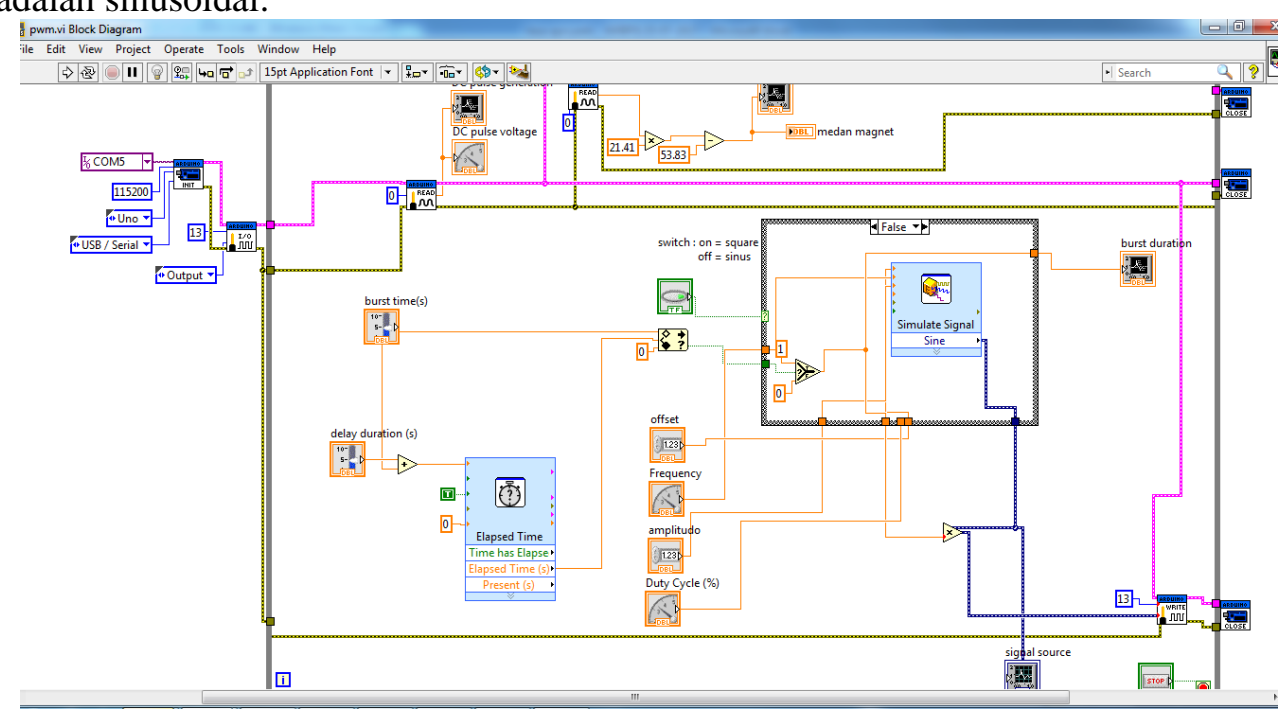

Gambar 3. Block diagram LabVIEW

Sebelum mengatur front panel, terlebih dahulu program harus diatur melalui block diagram. Pada block diagram dideklarasikan setiap variabel yang dibutuhkan pada front panel, serta menginisialisasi Visa yang akan menghubungkan komputer dengan mikro kontroler. Visa inisialisasi menjadi 3 bagian yaitu VisaSerial, VisaWrite, dan VisaRead. VisaSerial digunakan sebagai inisialisasi setiap port mulai dari baudrate hingga port yang akan digunakan pada komputer. Sedangkan VisaWrite berfungsi menulis apa yang diminta oleh program ke dalam mikrokontroler, dan fungsi dari VisaRead adalah sebagai pembaca apa yang akan diperintahkan oleh mikro kontroler pada program. Penerimaan data dapat langsung diambil sesuai dengan pengaturan atau format data yang telah dikirim sebelumnya dari mikro kontroler. Data yang diterima dari mikro kontroler dapat di export ke dalam Microsoft Excel

\section{HASIL DAN PEMBAHASAN}

\section{Karakterisasi}

Karakterisasi sensor dilakukan dengan cara mencari persamaan hubungan antara medan magnet perhitungan dengan tegangan keluaran sensor, dengan meletakkan sensor di pusat kumparan dan kumparan diberi variasi arus dari 0-1 A.

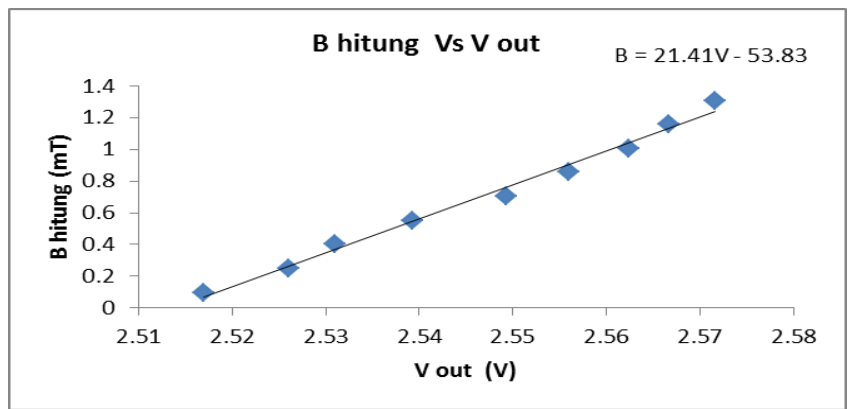

Gambar 4. Hubungan medan magnet hitung terhadap tegangan keluaran sensor 
Dari grafik tersebut di dapat fungsi transfer dari sensor Hall Effect adalah $\mathrm{B}=21.41 \mathrm{~V}+53.83$, dengan V adalah tegangan Vout (V) dan B adalah medan magnet hitung (mT). Pengujian selanjutnya dilakukan dengan membandingkan kuat medan magnet yang dihasilkan alat ukur Gaussmeter dengan sensor magnetic menggunakan variasi arus dari $0.10-1.00 \mathrm{~A}$.

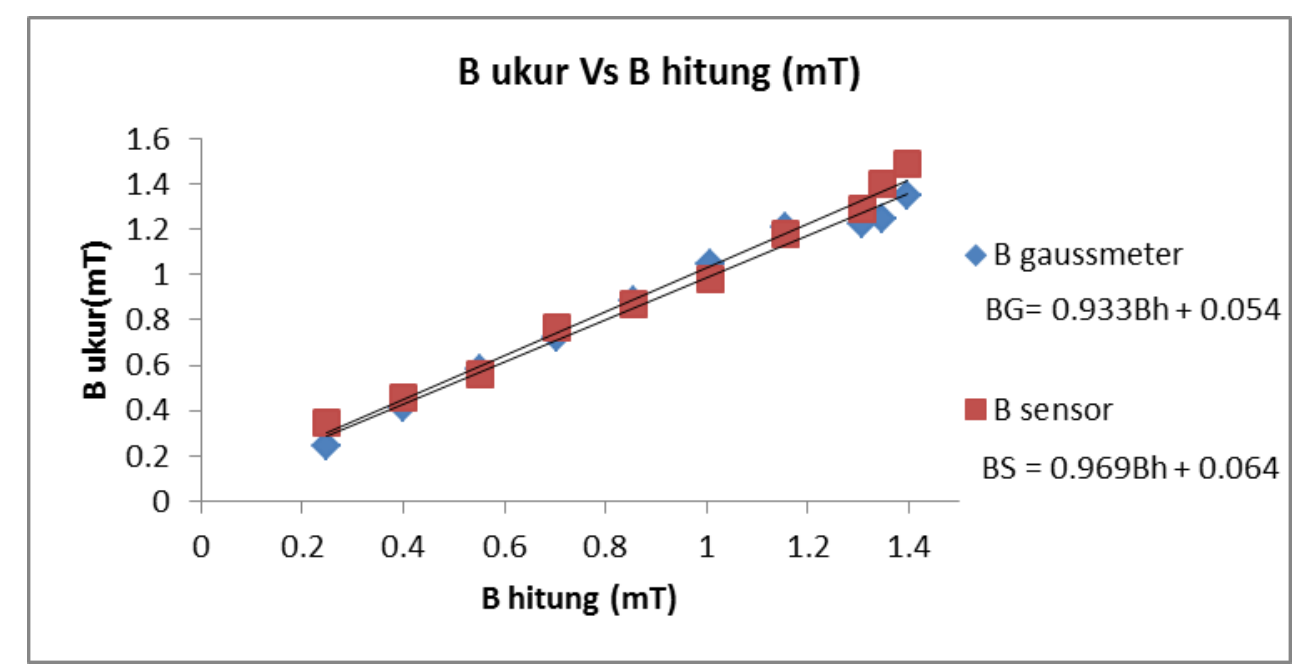

Gambar 5. Hubungan antara medan magnet terukur terhadap medan magnet perhitungan

Gaussmeter yang digunakan adalah tipe IDR-324, dan persamaan linier yang didapatadalah BG = $0.933 \mathrm{Bh}+0.054$. Variabel BG menunjukan nilai medan magnet terukur oleh gaussmeter, sedangkan variabel Bh menunjukan nilai medan magnet perhitungan, sedangkan hubungan medan magnet yang terukur oleh sensor dengan niali medan magnet perhitungan didapat persamaa BS $=0.969 \mathrm{Bh}+0.064$, dengan Bh adalah nilai perhitungan dan BS adalah nilai medan magnet yang terukur oleh sensor. Dari garis linear pada grafik dapat dikatakan bahwa nilai terukur pada sensor dan Gaussmeter mendekati nilai perhitungan teori kumparan Helmholtz.

Selanjutnya dilakukan pengukuran medan magnet di kumparan Helmholtz dengan mengaliri arus DC sebesar 0.28 A. Data diambil pada sumbu X secara manual dengan menggeser batang ulir setiap satu $\mathrm{cm}$. Berikut grafik hubungan distribusi medan magnet terhadap posisi.

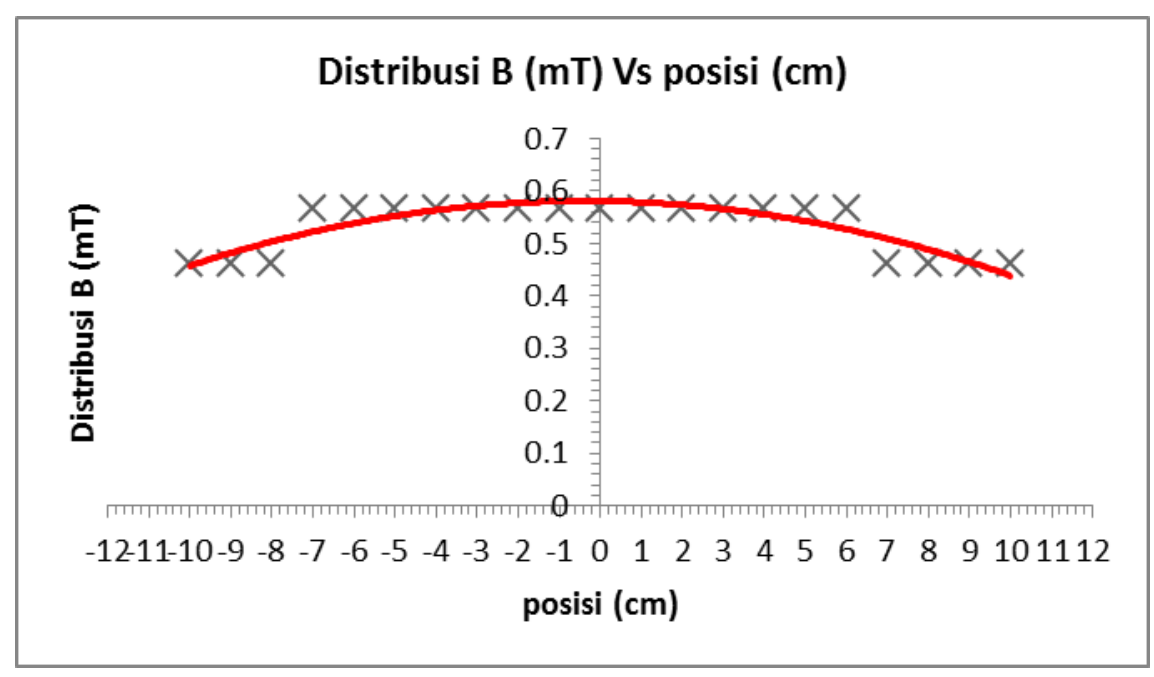

Gambar 6. Grafik medan magnet terhadap posisi $\mathrm{x}$

Grafik di atas menunjukan bahwa nilai medan magnet di sekitar pusat kumparan memiliki nilai yang hampir seragam. Posisi yang baik untuk ditempatkan hewan percobaan untuk di pajan adalah di tengah-tengah kumparan . 
Untuk mengetahui hubungan medan magnet yang dihasilkan dengan duty cycle, dilakukan pengujian dengan memvariasikan duty cycle dari 10\%-90\%, arus DC 0.28A dan frekwensi $125 \mathrm{~Hz}$. Berikut ini adalah grafik hubungan medan magnet dengan duty cycle.

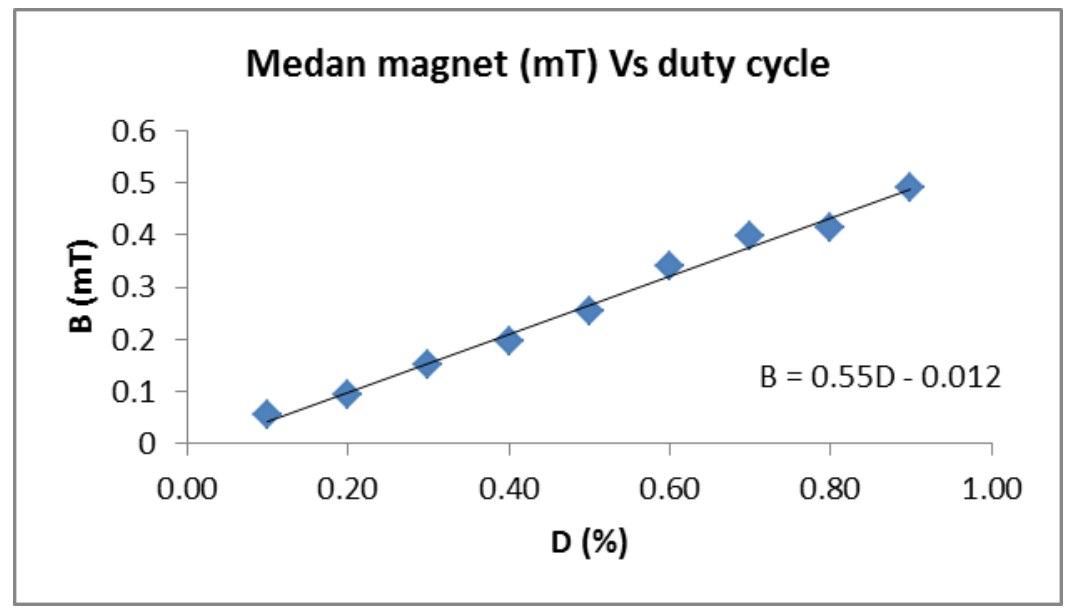

Gambar 1. Grafik hubungan medan magnet dengan duty cycle

Berdasarkan grafik di atas hubungan medan magnet dengan duty cycle linear dengan persamaan linear nya adalah $\mathrm{B}=1.783 \mathrm{D}+0.026$, dengan $\mathrm{D}$ adalah duty cycle dan $\mathrm{B}$ adalah medan magnet yang dihasilkan sensor. Dari grafik dapat disimpulkan bahwa hubungan medan magnet dengan duty cycle sesuai dengan teori dimana semakin kecil duty cycle maka rata-rata medan magnet yang dihasilkan semakin kecil.

Hubungan antara medan magnet dengan frekuensi diketahui dengan memvariasikan frekuensi mulai $25-250 \mathrm{~Hz}$, pada signal source square dan sinus, duty cycle $50 \%$ pada signal square dan arus DC 0.28 A.

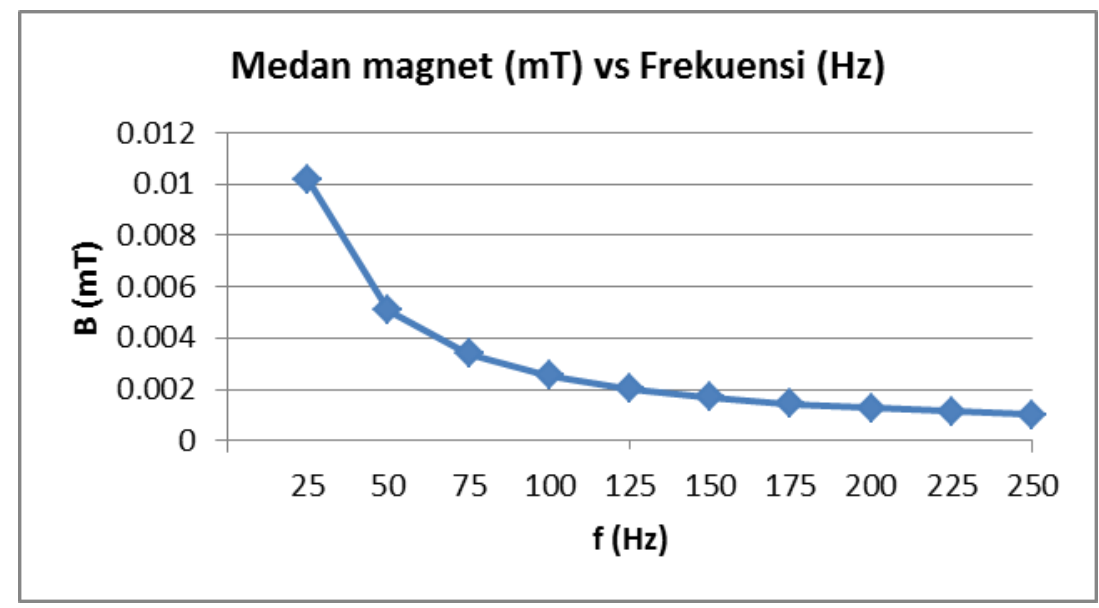

Gambar 8. Grafik hubungan medan magnet dengan frekuensi

Dari grafik di atas dapat diketahui bahwa medan magnet dipengaruhi oleh frekuensi semakin besar nilai frekuensi, semakin kecil medan magnet rata-rata nya.

\section{Uji coba alat}

Telah dilakukan uji coba alat PEMF untuk penelitian bioelektromagnetik menggunakan hewan coba tikus putih Spraque Dawley yang dibuat fraktur model non union. Uji coba tersebut dilakukan di laboratorium hewan Balitbang Depkes dengan persetujuan komite etik FKUI no 
456/UN2.F1/ETIK/2017. Pajanan PEMF diberikan secara kontinue dan intermittent selama 4 jam/hari selama 28 hari, seperti terlihat pada gambar dibawah ini :
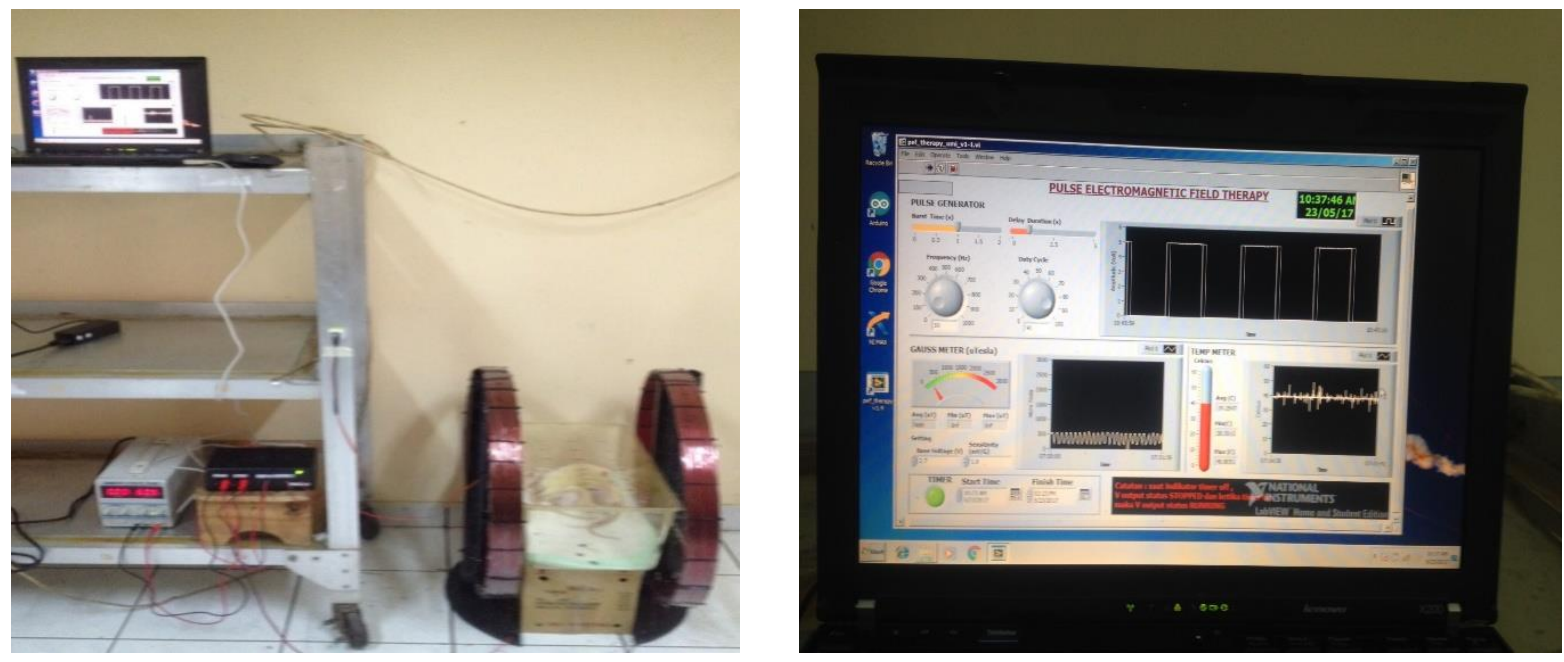

Gambar 8. Grafik hubungan medan magnet dengan frekuensi

Pada penelitian lanjutan akan dilakukan analisis penyembuhan fraktur secara molekuler dan biokimia untuk menilai perbedaan kecepatan penyembuhan fraktur karena pajanan PEMF secara kontinue dan intermittent.

\section{SIMPULAN}

Telah dilakukan desain, pembuatan dan uji coba alat PEMF yang mampu menghasilkan medan magnet seragam dengan intensitas 0.5-2 mT dengan parameter fisis yang bisa diatur dalam prototipe alat ini adalah tipe waveform, frekwensi, duty cycle, burst time, exposure time dan data yang dapat disimpan dan di export pada ms. Excel. Hasil penelitian ini dapat digunakan sebagai sarana penelitian bioelektromagnetik.

\section{UCAPAN TERIMAKASIH}

Penulis mengucapkan terimakasih kepada FMIPA UNJ yang telah membiayai penelitian ini melalui Program Hibah Penelitian Fakultas tahun 2017 dengan nomor kontrak... dan laboratorium Fisika Instrumentasi Medik UI yang memfasilitasi penelitian ini.

\section{DAFTAR ACUAN}

[1] B. Wade, "A review of pulse eectromagnetic field mechanism at a cellular level : a rationale for clinical use", in American Journal of Health Research, 2013; 1(3):51-55.

[2] A. Ongaro, A. Pellati, L. Bagheri, C. Fortini, S. Setti, \& M.D. Mattei, Pulsed Electromagnetic Fields Stimulate Osteogenic Differentiation in Human Bone Marrow and Adipose Tissue Derived Mesenchymal Stem Cells, New York: Bioelectromagnetic Wiley Periodical, 2014, pp 426-436.

[3] H. F. Shi, J. Xiong, Y. X. Chen, J. F. Wang, X. S. Qiu, Y. H. Wang, \& Y. Qiu, Early application of pulsed electromagnetic field in the treatment of postoperative delayed union of long bone fracture, BMC Muskuloskeletal Disorder, 2013, 14-35.

[4] W. H. Chang, "Bone defect healing enhanced by pulse electromagnetic fields stimulation : invitro bone organ culture model". In Journal of Medical and Biological Engineering, 2005, 25(1):27-32. 
[5] Aliyadollahpour, "Therapeutic Application of Electromagnetic Fields in Musculoskeletal Disorder”, in Biomedical \& Pharmacology Journal, 2014, Vol 7(1), 23-32.

[6] A. Pilla, Mechanism and therapeutic applications of time varying and static magnetic field. Handbook of Biological Effects of Electromagnetic Field, $3^{\text {rd }}$ edition, CRC Press, 2006. 